\title{
Formulasi dan Evaluasi Lotion Kombinasi Magnesium Oil dan Minyak Biji Kelor (Moringa Seed Oil)
}

\section{Lotion Formulation and Evaluation Combination of Magnesium Oil and Moringa Seed Oil}

\author{
Yulyuswarni \\ Jurusan Farmasi, Politeknik Kesehatan Tanjung Karang, Indonesia
}

\section{ARTICLE INFO}

\section{Article history}

Received date

01 Mar 2021

Revised date

29 Mar 2021

Accepted date

19 Apr 2021

\section{Keywords:}

Antioxidant;

Lotion;

Magnesium lotion;

Moringa;

Seed oil.

Kata kunci:

Antioksidan;

Lotion;

Magnesium lotion;

Moringa;

Seed Oil.

\author{
ABSTRACT/ ABSTRAK
}

Magnesium plays a role in nearly 600 important metabolic and enzymatic reactions in the body. In developing countries, $10-30 \%$ of people have a magnesium deficiency. Magnesium deficiency can result in migraines, insomnia, leg cramps, anxiety, arrhythmias, diabetes mellitus, hypertension, etc. Transdermal magnesium supplementation has been shown to be useful as a muscle relaxant in treating leg cramps. Moringa Oleifera Seed Oil contains antioxidants, anti-aging, amino acids, collagen, omega 3,6 and 9, complete vitamins and minerals that are widely used in cosmetics. This experimental study aims to obtain a combination lotion formula of magnesium oil and moringa seed oil that meets the requirements and functions as an intake of magnesium and antioxidants. The data obtained were compared with the standard requirements for topical lotion preparations. The formula is designed with a magnesium chloride concentration of $250 \mathrm{mg} / 5 \mathrm{ml}$, with four concentrations of moringa seed oil F1 (3\%), F2 $(6 \%), \mathrm{F} 3(9 \%)$, and F4 (12\%). Based on the results of the study, it was obtained that the dosage data was white, the semi-solid texture was easy to pour with a lavender aroma. All the formulas meet the requirements of $\mathrm{pH}(5,0-5,5)$ and some of the formulas meet the requirements of dispersion, specific gravity, viscosity. The Antioxidant activity of all formulas is very weak. Only one formula (F4) meets all the requirements for the lotion preparation.
Magnesium berperan dalam hampir 600 reaksi metabolisme dan enzimatik penting dalam tubuh. Masyarakat di negara berkembang 10-30\% mengalami defisiensi magnesium. Defisiensi magnesium dapat mengakibatkan migrain, insomnia, kaki kram, anxiety, aritmia, diabetes mellitus, dan hipertensi. Suplementasi magnesium secara transdermal telah terbukti bermanfaat sebagai muscle relaxant dalam mengatasi kaki kram. Minyak biji kelor (moringa seed oil) mengandung antioksidan, antiaging, asam amino, collagen, omega 3,6 dan 9, vitamin dan mineral yang lengkap sehingga banyak digunakan dalam kosmetik. Penelitian dengan desain experimental ini bertujuan untuk mendapatkan formula lotion kombinasi magnesium oil dan moringa seed oil yang memenuhi syarat dan berfungsi sebagai intake magnesium dan antioksidan. Data yang diperoleh dibandingkan dengan persyaratan standar sediaan topikal lotion. Formula dirancang dengan konsentrasi magnesium khlorida $250 \mathrm{mg} / 5 \mathrm{ml}$ dengan 4 konsentrasi moringa seed oil F1(3\%), F2 (6\%), F3 (9\%), dan F4 (12\%). Berdasarkan hasil penelitian diperoleh data sediaan berwarna putih, tekstur setengah padat, mudah dituang dengan aroma khas lavender. Seluruh formula memenuhi persyaratan $\mathrm{pH}(5,0-5,5)$, beberapa formula memenuhi persyaratan daya sebar, bobot jenis, dan viskositas. Aktivitas antioksidan semua formula sangat lemah. Hanya satu formula (F4) yang memenuhi keseluruhan persyaratan sediaan lotion.

Corresponding Author:

Yulyuswarni

Jurusan Farmasi, Politeknik Kesehatan Tanjung Karang, Indonesia

Email: yulyuswarni89@gmail.com 


\section{PENDAHULUAN}

Magnesium $\left(\mathrm{Mg}^{2+}\right)$ merupakan kation intra seluler kedua terbanyak setelah kalium dan memiliki peran sangat penting dalam metabolisme tubuh. Magnesium terlibat dalam hampir 600 reaksi enzymatik termasuk dalam metabolisme energi dan sintesa protein. Magnesium memainkan peran fisiologis yang penting, terutama di otak, jantung, dan otot rangka. Suplementasi magnesium telah terbukti bermanfaat dalam pengobatan antara lain, preeklamsi, migrain, depresi, penyakit arteri koroner, dan asma (Kass, et al., 2017).

Defisiensi magnesium subklinis di negara berkembang terjadi pada $10-30 \%$ populasi yang ditunjukkan dari kadar serum $<0,80 \mathrm{mmol} / \mathrm{L}$. Defisiensi magnesium akut ataupun kronis sulit didiagnosa, karena jaringan yang rusak tidak mudah terdeteksi dari awal. Beberapa tanda defisiensi magnesium diantaranya aritmia, anxiety, kram, katarak, hipertensi, migrain, osteoporosis, vertigo, tremor, photosensitivitas dan lain-lain (DiNicolantonio, et al., 2018).

Magnesium diekskresikan melalui urine, sehingga kelebihan asupan magnesium akan dibuang melalui urine. Sementara magnesium dalam dosis besar dalam suplemen makanan atau obat-obatan dapat mengakibatkan efek laxative atau diare disertai mual dan kram perut (National Institutes of Health NIH, 2018). Larutan magnesium klorida sering disebut "magnesium oil" telah banyak digunakan sebagai upaya intake magnesium secara topikal/transdermal. Sediaan magnesium topikal dapat kita jumpai sebagai magnesium oil, lotion, cream, body butter, gel, dan lain sebagainya.

Radikal bebas yang berupa sinar ultraviolet (UV) dalam kondisi berlebih adalah salah satu penyebab dari kerusakan kulit. Diperlukan antioksidan yang melawan radikal bebas dari hasil metabolisme tubuh, polusi udara, cemaran makanan, sinar matahari dan lain sebagainya. Antioksidan sangat diperlukan oleh tubuh untuk mengatasi dan mencegah stress oksidatif, yang berperan penting dalam patofisologi terjadinya proses penuaan dan penyakit degeneratif yang saat ini merupakan masalah kesehatan yang serius (Werdhasari, 2014).

Indonesia memiliki berbagai macam tanaman dengan khasiat antioksidan. Salah satunya adalah tanaman kelor (Moringa Oleifera $L$ ) yang merupakan tanaman obat berkhasiat sebagai stimulan jantung dan peredaran darah, antitumor, antipiretik, antiepilepsi, antiinflamasi, antiulser, antidiuretik, antihipertensi, menurunkan kolesterol, antioksidan, antidiabetik, antibakteri, dan antijamur (Krisnadi, 2015).

Berdasarkan uji fitokimia kelor (Moringa Oleifera L.) mengandung tanin, steroid dan triterpenoid, flavonoid, saponin, antarquinon, dan alkaloid dimana semua merupakan antioksidan. Salah satu kelompok flavonoid yang dimiliki kelor adalah kuersetin yang memiliki kekuatan antioksidan 4-5 kali lebih tinggi dibandingkan vitamin C dan E (Krisnadi, 2015).

Biji kelor mengandung 35-40\% minyak, memiliki kualitas yang hampir sama dengan minyak zaitun (Warra, 2014). Minyak biji kelor merupakan golongan edible oil yang memiliki aktivitas sebagai antioksidan, antiaging, emolien, perawatan rambut dan pencerah kulit. Minyak kelor merupakan minyak yang paling dicari dalam formula produk perawatan kulit dan kosmetika kelas atas, karena mengandung anti oksidan kuat, antiaging, antiinflamasi, asam lemak tak jenuh, mudah menyerap di kulit, dan kaya dengan vitamin dan mineral sebagai nutrisi kulit (Krisnadi, 2015). Sediaan magnesium lotion maupun moringa lotion sudah tersedia di pasaran, tetapi belum tersedia sediaan lotion yang merupakan kombinasi keduanya. Oleh karena itu hasil penelitian formulasi lotion yang mengandung moringa seed oil yang berkhasiat sebagai antioksidan, antiaging dan dikombinasikan dengan magnesium sebagai suplemen magnesium secara transdermal merupakan inovasi dalam pemanfaatan dan pengembangan tanaman Kelor dalam teknologi farmasi menjadi sediaan Cosmeceutical yang bernilai ekonomi.

\section{METODE}

Penelitian ini menggunakan metode eksperimental dengan analisis deskriptif, dilakukan dengan merancang formula, teknik formulasi, dan evaluasi mutu sediaan lotion. Evaluasi mutu yang dimaksud dalam penelitian ini meliputi sifat organoleptik, homogenitas, $\mathrm{pH}$, daya sebar, bobot jenis, viskositas, dan daya antioksidan.

Penelitian ini dilakukan di laboratorium Farmasetika Jurusan Farmasi Poltekkes Tanjungkarang, dan Laboratorium Terpadu Sentra Inovasi Teknologi Universitas Lampung, pada bulan Maret-September 2020.

Sebelum penelitian berlangsung telah dilakukan kajian etik dan telah mendapatk Keterangan Laik Etik dengan nomor sertifikat 244/KEPK-TJK/IV/2020. 
Alat-alat yang digunakan pada penelitian yaitu beaker glass $100 \mathrm{ml}$ dan $250 \mathrm{ml}$, kaca arloji, corong, batang pengaduk, hand blender, hot plate, $\mathrm{pH}$ meter, termometer, timbangan analitik, kertas saring.

Bahan-bahan yang digunakan meliputi moringa seed oil yang diperoleh dari PT Moringa Organik Indonesia, shea butter (Butyrospermum parkii butter), magnesium chlorida, stearic acid, emulsfying wax, gliserin, xanthan gum, arrowrot powder, Triethanolamin (TEA), opthipen plus, lavender essential oil, dan aquadest.

Formulasi lotion diawali dengan pembuatan magnesium oil dengan melarutkan $\mathrm{MgCl}_{2}$ dengan aquadest hangat, kemudian disaring. Panaskan kembali hingga suhu $70^{\circ} \mathrm{C}$. Selanjutnya phase minyak yang terdiri dari shea butter, stearic acid, emulsying wax, dan moringa seed oil dipanaskan sampai suhu $70^{\circ} \mathrm{C}$. Pada kondisi suhu yang sama, tambahkan phase air ke phase minyak sambil diaduk dengan hand blender sehingga terbentuk corpus emulsi. Aduk terus sampai suhu $40^{\circ} \mathrm{C}$, kemudian masukkan gliserin, Arrowrot powder, dan xanthan gum, aduk sampai homogen. Selanjutnya setelah dingin tambahkan preservative optiphen plus, lavender essential oil dan tambahkan sisa aquadest, , cek $\mathrm{pH}$ dan lakukan adjuster $\mathrm{pH}$ dengan TEA, sehingga diperoleh $\mathrm{pH}$ dalam range 4,5-6,5. Selanjutnya dilakukan evaluasi terhadap mutu sediaan meliputi:

1. Evaluasi organoleptis

Evaluasi terhadap tekstur, warna, dan aroma dengan pengamatan secara langsung oleh peneliti (Suryadevara V, Doppalapudi S \& Anne R, 2018).

2. Uji homogenitas

Uji homogenitas dengan cara melihat penampilan visual dan dengan sentuhan Sediaan dinyatakan homogen apabila tidak terdapat butiran kasar (Suryadevara V, Doppalapudi S \& Anne R, 2018).

3. Uji pH

Larutkan 0,5gr sediaan lotion dengan $5 \mathrm{ml}$ aquabidest. Celupkan $\mathrm{pH}$ meter yang sudah dikalibrasi, angka yang ditunjukkan $\mathrm{pH}$ meter merupakan $\mathrm{pH}$ sediaan. Uji $\mathrm{pH}$ dilakukan pengulangan sebanyak 3 kali
(Sugihartini, et al., 2019). pH sediaan hendaknya berada dalam range $\mathrm{pH}$ kulit yaitu 4,5- 6,5 (Tranggono, 2007).

4. Uji bobot jenis

Evaluasi bobot jenis dilakukan dengan metoda pengukuran menggunakan piknometer. Bobot jenis sediaan adalah perbandingan bobot jenis baku (air) dengan bobot jenis lotion dengan volume yang sama pada suhu $25^{\circ} \mathrm{C}$ (Badan Standardisasi Nasional, 1996).

5. Uji daya sebar

Sebanyak 1gram sediaan di tempatkan diantara dua kaca berukuran 20x20cm selama 1 menit. Berikan beban diatas kaca seberat $125 \mathrm{gr}$. Ukur diameter penyebaran setelah 1 menit. Daya sebar yang baik untuk semi solid adalah $5-7 \mathrm{~cm}$ (Sugihartini, et al., 2019).

6. Uji viskositas

Evaluasi kekentalan dilakukan dengan menggunakan alat viscometer HAAKE. Rotor di tempatkan di tengah-tengah beaker glass yang berisi sediaan, jalankan rotor dan amati jarum penunjuk viskositas. Angka yang ditampilkan menunjukkan viskositas sediaan. Menurut BSNI (Badan Standardisasi Nasional, 1996) dalam Sugihartini, et al., (2019) Standar Nasional Indonesia (SNI) No. 16-4399-1996 persyaratan viskositas untuk sediaan tabir surya 2000-50.000 cps.

7. Uji daya antioksidan

Evaluasi daya antioksidan sediaan dilakukan dengan mengukur daya peredaman radikal bebas DPPH (1,1-diphenyl-2 picrylehydrazyl) oleh bahan aktif dengan pembanding asam askorbat. Sampel dibuat dalam beberapa konsentrasi kemudian dilarutkan dalam larutan DPPH, diukur absorbansi peredaman dengan menggunakan spektrofotometer UV-Vis. Nilai absorbansi yang diperoleh dihitung persentasi penghambatan radikal bebas yang kemudian ditentukan $\mathrm{IC}_{50}$ melalui persamaan linear, nilai tersebut menunjukkan kekuatan aktivitas antioksidannya (Suphachai, 2014). 
HASIL

Tabel 1. Hasil Evaluasi Organoleptik Lotion Kombinasi Magnesium Oil dan Moringa Seed Oil

\begin{tabular}{lcccc}
\hline Formula & \multicolumn{3}{c}{ Organoleptik } \\
\cline { 2 - 5 } Lotion & Warna & Aroma & Homogenitas & Tekstur \\
\hline F0 & Putih & Khas Lavender & Homogen & Setengah padat mudah dituang \\
F1 & Putih & Khas Lavender & Homogen & Setengah padat mudah dituang \\
F2 & Putih & Khas Lavender & Homogen & Setengah padat mudah dituang \\
F3 & Putih & Khas Lavender & Homogen & Setengah padat mudah dituang \\
F4 & Putih & Khas Lavender & Homogen & Setengah padat mudah dituang \\
\hline
\end{tabular}

Berdasarkan tabel 1 dapat diketahui organoleptik semua sediaan berwarna putih, homogen, dengan tekstur setengah padat dengan aroma khas lavender, karena dalam formula terdapat penambahan corigen odoris minyak essential lavender yang akan memberikan efek menenangkan.

Tabel 2. Hasil Evaluasi pH Lotion Kombinasi Magnesium Oil dan Moringa Seed Oil

\begin{tabular}{|c|c|c|c|c|c|}
\hline \multirow{2}{*}{$\begin{array}{c}\begin{array}{c}\text { Formula } \\
\text { lotion }\end{array} \\
\mathrm{F} 0\end{array}$} & \multicolumn{3}{|c|}{$\begin{array}{c}\text { pH } \\
\text { (3 kali } \\
\text { pengulangan) }\end{array}$} & \multirow{2}{*}{$\begin{array}{c}\begin{array}{c}\text { Range } \\
\text { pH }\end{array} \\
5,0-5,1\end{array}$} & \multirow{2}{*}{$\begin{array}{l}\text { Ket } \\
\text { MS }\end{array}$} \\
\hline & 5,1 & 5,1 & 5,0 & & \\
\hline $\mathrm{F} 1$ & 5,5 & 5,5 & 5,5 & 5,5 & MS \\
\hline $\mathrm{F} 2$ & 5,2 & 5,3 & 5,2 & $5,2-5,3$ & MS \\
\hline F3 & 5,1 & 5,1 & 5,2 & $5,1-5,2$ & MS \\
\hline F4 & 5,5 & 5,5 & 5,5 & 5,5 & MS \\
\hline
\end{tabular}

Catatan :

Persyaratan pH: 4,5-6,5

MS = Memenuhi persyaratan

TMS= Tidak Memenuhi persyaratan

Hasil evaluasi $\mathrm{pH}$ berdasarkan tabel 2 semua formula memenuhi persyaratan.

Tabel 3. Hasil Evaluasi Daya Sebar Lotion Kombinasi Magnesium Oil dan Moringa Seed Oil

\begin{tabular}{|c|c|c|c|c|c|}
\hline \multirow{2}{*}{$\begin{array}{l}\text { Formula } \\
\text { lotion }\end{array}$} & \multicolumn{3}{|c|}{$\begin{array}{c}\text { Diameter } \\
\text { Penyebaran } \\
\text { (cm) (3 kali } \\
\text { pengulangan) }\end{array}$} & \multirow{2}{*}{$\begin{array}{r}\text { Rerata } \\
9,03\end{array}$} & \multirow{2}{*}{$\begin{array}{l}\text { Ket } \\
\text { TMS }\end{array}$} \\
\hline & 9,0 & 9,0 & 9,1 & & \\
\hline $\mathrm{F} 1$ & 7,2 & 7,0 & 7,2 & 7,13 & TMS \\
\hline F2 & 7,1 & 7,0 & 7,1 & 7,06 & MS \\
\hline F3 & 6,4 & 6,3 & 6,3 & 6,3 & MS \\
\hline $\mathrm{F} 4$ & 6,3 & 6,1 & 6,3 & 6,23 & MS \\
\hline
\end{tabular}

Berdasarkan tabel 3 diketahui hanya F2, F3 dan F4 memenuhi persyaratan daya sebar, dengan rerata daya sebar 6,23 sampai dengan $7,06 \mathrm{~cm}$
Tabel 4. Hasil Evaluasi Bobot Jenis Lotion Kombinasi Magnesium Oil dan Moringa Seed Oil

\begin{tabular}{lcc}
\hline $\begin{array}{c}\text { Formula } \\
\text { lotion }\end{array}$ & $\begin{array}{c}\text { Bobot Jenis } \\
(\mathbf{g} / \mathbf{m l})\end{array}$ & Ket \\
\hline F0 & 0,9634 & MS \\
F1 & 1,0269 & MS \\
F2 & 0,9871 & MS \\
F3 & 0,9400 & TMS \\
F4 & 0,9930 & MS \\
\hline
\end{tabular}

Tabel 4 menunjukkan hasil evaluasi bobot jenis menunjukkan F0, F1, F2 dan F4 memenuhi persyaratan bobot jenis, sedangkan F3 tidak memenuhi persyaratan.

Tabel 5. Hasil Evaluasi Viskositas Lotion Kombinasi Magnesium Oil dan Moringa Seed Oil

\begin{tabular}{lrl}
\hline $\begin{array}{c}\text { Formula } \\
\text { lotion }\end{array}$ & \multicolumn{1}{c}{$\begin{array}{c}\text { Viskositas } \\
\text { (cps) }\end{array}$} & Ket \\
\hline F0 & 759 & TMS \\
F1 & 448 & TMS \\
F2 & 1860 & TMS \\
F3 & 3550 & MS \\
F4 & 2720 & MS \\
\hline
\end{tabular}

Catatan: Persyaratan 2000-50.000 cps

Berdasarkan tabel 5 diketahui F0, F1 dan F2 tidak memenuhi syarat viskositas

Tabel 6. Hasil Evaluasi Daya Antioksidan Lotion Kombinasi Magnesium Oil dan Moringa Seed Oil

\begin{tabular}{lcc}
\hline $\begin{array}{c}\text { Formula } \\
\text { lotion }\end{array}$ & $\begin{array}{c}\mathbf{I C}_{\mathbf{5 0}} \\
(\mathbf{p p m})\end{array}$ & Ket \\
\hline F1 & 4393,57 & Sangat lemah \\
F2 & 1083,54 & Sangat lemah \\
F3 & 2197,73 & Sangat lemah \\
F4 & 1581,87 & Sangat lemah \\
\hline
\end{tabular}

Berdasarkan tabel 6 semua formula memiliki daya antioksidan lemah. 


\section{PEMBAHASAN}

Formulasi lotion kombinasi magnesium oil dan moringa seed oil, diawali dengan pembuatan magnesium oil dengan cara melarutkan garam magnesium klorida dengan aquadest panas sejumlah sama banyak dengan phase minyak, kemudian disaring. Larutan ini dikenal dengan magnesium oil, karena sifatnya memberikan rasa berminyak ketika dioleskan pada kulit. Phase minyak (phase A) terdiri dari moringa seed oil, shea butter, emulsifying wax dan acid stearic, dilebur sampai suhu $70^{\circ} \mathrm{C}$. Magnesium oil yang telah disaring, dipanaskan kembali sehingga mencapai suhu $70^{\circ} \mathrm{C}$. Pada saat berada pada suhu yang sama, tambahkan phase air (phase B) ke phase minyak (phase A) sedikit demi sedikit, aduk dengan hand blender sampai terbentuk corpus emulsi. Pengadukan berlanjut sampai suhu turun berkisar $40^{\circ} \mathrm{C}$. Kemudian masukkan phase $\mathrm{C}$ satu persatu yaitu gliserin yang berfungsi sebagai humektan yang dapat mencegah penguapan air dari permukaan kulit sehingga menjaga kelembaban kulit.

Arrowrot powder untuk mengurangi kesan berminyak pada sediaan, sedangkan xanthan gum berfungsi sebagai pengental yang dapat meningkatkan stabilitas sediaan. Kemudian masukkan phase $\mathrm{D}$ yang terdiri dari optiphen plus dan minyak essential oil Lavender serta TEA sebagai adjuster $\mathrm{pH}$. Optiphen plus merupakan preservative natural spektrum luas terhadap bakteri, ragi dan jamur, sehingga banyak digunakan untuk krim, tabir surya, lotion, shampoo, sabun mandi dan kosmetik. Penggunaan optiphen plus 0,75-1,5\%. Pencampuran corigen odoris dilakukan pada suhu $40^{\circ} \mathrm{C}-50^{\circ} \mathrm{C}$ untuk mencegah distorsi parfum. Terakhir lakukan pengenceran phase luar dengan aquadest yang tersisa.

Tampilan visual organoleptik sediaan berwarna putih, dengan aroma khas lavender, tekstur setengah padat mudah dituang. Aroma khas lavender berasal dari minyak esensial lavender yang diharapkan memberikan efek menenangkan dan rileks. Seluruh sediaan homogen yang ditunjukkan tidak terdapat partikel kasar ketika dioleskan pada kaca objek dan dioleskan di tangan. Evaluasi pH dilakukan untuk mengetahui derajat keasaman sediaan. Sediaan topikal hendaknya memiliki $\mathrm{pH}$ yang sama atau mendekati fisiologis "mantel asam kulit" yaitu berkisar 4,5-7 (Agoes, 2015) sedangkan menurut Tranggono (2007) $\mathrm{pH}$ sediaan sebaiknya mendekati $\mathrm{pH}$ kulit yaitu 4,56,5, sementara Badan Standardisasi Nasional, (1996) mempersyaratkan $\mathrm{pH}$ untuk sediaan tabir surya adalah 4,5-8,0. Apabila sediaan terlalu asam dapat mengakibatkan kulit iritasi dan apabila terlalu basa dapat mengakibatkan kulit menjadi kering. Sediaan lotion kombinasi magnesium oil $250 \mathrm{mg} / 5 \mathrm{ml}$ dan moringa seed oil pada konsentrasi 3\%, 6\%, 9\% dan $12 \%$ memenuhi persyaratan sediaan topikal yaitu memiliki range $\mathrm{pH} 5.0-5,5$, sehingga sediaan ini aman digunakan untuk kulit.

Salah satu evaluasi mutu lotion yang diperlukan adalah evaluasi daya sebar. Menurut Garg, et al, (2002) dalam Sugihartini, et al., (2019) daya sebar sediaan topikal antara $5-7 \mathrm{~cm}$. Daya sebar yang baik akan mempermudah ketika diaplikasikan pada kulit. Pada sediaan F0 memiliki daya sebar $9,03 \mathrm{~cm}$. Hal ini disebabkan karena pada F0 tanpa adanya minyak biji kelor sehingga phase minyak hanya terdapat $7 \%$ dari keseluruhan formula. Sedangkan F1 phase minyak nya menjadi $10 \%$ dengan $3 \%$ minyak biji kelor. Proporsi phase dalam dapat mempengaruhi viskositas, dan viskositas mempengaruhi kepada daya sebar serta aliran lotion (Agoes, 2015).

Viskositas emulsi akan meningkat sejalan dengan meningkatnya konsentrasi phase dalam, dan paling efektif jika konsentrasi phase dalam mendekati $40 \%$. Pada formula 2,3 dan 4, phase dalam (minyak) berturut-turut adalah 13\%, 16\% dan 19\%. Sehingga Formula 2,3,4 dengan phase minyak yang cukup memiliki daya sebar lebih kecil. Sediaan dengan viskositas yang berbedabeda, akan menghasilkan daya sebar yang berbeda pula, karena hambatan pada masingmasing sediaan untuk menyebar berbeda juga besarnya. Daya sebar yang baik menyebabkan kontak antara obat dengan kulit menjadi luas, sehingga absorpsi obat berlangsung cepat

Penentuan bobot jenis (BJ) suatu sediaan cair dilakukan dengan membandingkan antara bobot sediaan yang akan diukur (lotion) dengan bobot kontrol (air) pada suhu dan volume yang sama. Bobot jenis mempengaruhi terhadap stabilitas sediaan redispersi lapisan (Agoes, 2015). Salah satu bentuk ketidak stabilan sediaan emulsi, terbentuknya creaming, Kecepatan creaming proporsional terhadap perbedaan bobot jenis diantara fasa minyak dan air, viskositas fasa kontinu, dan ukuran partikel dari fasa terdispersi. Fakta ini menunjukkan bahwa kreming dapat di minimalkan/dikurangi dengan cara pengaturan bobot jenis dari masing-masing fasa untuk meminimalkan perbedaan BJ, menurunkan ukuran partikel fasa internal, menggunakan tahap homogenisasi atau menstabilkan ukuran partikel dan menaikkan viskositas fasa kontinu melalui penambahan pengental pada phase eksternal (Agoes, 2015). 
Viskositas adalah ukuran yang menyatakan kekentalan suatu cairan atau fluida. Evaluasi viskositas bertujuan untuk menilai kekentalan sediaan yang berhubungan dengan kemampuan daya ali/penyebaran viskositas merupakan tahanan suatu cairan untuk mengalir, makin tinggi nilai viskositas maka semakin besar tahanannya untuk mengalir. Viskositas sangat penting pada sediaan lotion, semakin tinggi viskositas, maka sediaan akan semakin sulit mengalir sehingga daya sebar juga semakin kecil. Semakin besar viskositas, maka sediaan akan semakin encer sehingga lebih mudah di oleskan dan mudah dituang dari kemasan. Viskositas sediaan magnesium moringa lotion berkisar 4483550 cps sedangkan menurut SNI persyaratan sediaan tabir surya 2000-50000 cps, meskipun sediaan tabir surya tidak selalu dalam bentuk lotion. Hanya sediaan F3 dan F4 yang memenuhi pesyaratan sediaan lotion yaitu F3 $3550 \mathrm{cps}$ dan F4=2720 cps. Perbedaan viskositas dipengaruhi oleh beberapa hal antara lain adanya hubungan linear antara viskositas emulsi dan viskositas phase kontinu. Makin besar volume phase dalam, makin besar viskositas nyata. Untuk mengatur viskositas emulsi, tiga faktor interaksi harus dipertimbangkan oleh pembuat formula yaitu viskositas emulsi $\mathrm{M} / \mathrm{A}$ dan $\mathrm{A} / \mathrm{M}$ dapat ditingkatkan dengan mengurangi ukuran partikel terdispersi, kestabilan emulsi ditingkatkan dengan pengurangan ukuran partikel, dan flokulasi atau penggumpalan, yang cenderung membentuk phase dalam yang dapat menjadi penstabil, walaupun ia meningkatkan viskositas. Biasanya viskositas emulsi meningkat dengan meningkatnya umur sediaan. (Lachman, et al, 2008).

Besaran viskositas F1, F2, F3 dan F4 dalam sediaan magnesium moringa lotion ini terlihat tidak linier, hal ini di duga karena distribusi ukuran partikel phase terdispersi yang tidak seragam, mengingat pengadukan dilakukan secara manual sehingga tidak dapat mengontrol kecepatan pengadukan. Salah satu faktor yang mempengaruhi aliran lotion menurut Agoes, (2015) adalah distribusi ukuran partikel fasa terdispersi. Diameter ukuran partikel yang seragam akan menghasilkan emulsi lebih berat (kental). Diameter lebih kecil akan lebih kental dari ukuran tetesan lebih besar apabila keseragaman setara.

Pengujian daya antioksidan magnesium moringa lotion menggunakan metode DPPH (1,1diphenil-2-picrylhydrazil). Nilai $\mathrm{IC}_{50}$ merupakan parameter yang digunakan untuk menyatakan kemampuan suatu bahan untuk menghambat aktivitas radikal dari DPPH sebesar 50\%. Ini berarti semakin kecil nilai $\mathrm{IC}_{50}$, semakin tinggi aktivitas antioksidannya (Molyneux, 2004).

Secara spesifik suatu senyawa dikatakan sebagai antioksidan sangat kuat jika nilai IC50 < 50, kuat jika $\mathrm{IC}_{50}$ bernilai 50-100, sedang jika $\mathrm{IC}_{50}$ bernilai 100-150, dan lemah jika $\mathrm{IC}_{50}$ bernilai 151-200 (Karim, et al., 2015). Hasil evaluasi daya antioksidan keseluruhan formula berada antara 1083,54 sampai 4393,57. Tampak disini keseluruhan formula sediaan magnesium moringa lotion memiliki daya anti oksidan sangat lemah. Berbeda dengan aktifitas antioksidan moringa seed oil yang diperoleh dari hasil ekstraksi menggunakan pelarut $\mathrm{N}$ Hexane, metanol dan etanol memiliki $\mathrm{IC}_{50}$ tergolong rendah karena konsentrasi yang dihasilkan untuk menghambat radikal bebas sebesar 50\% sangat tinggi (Sudaryanto, 2016). Sedangkan penelitian Unuigbe, CA., (2014), melaporkan ekstrak metanol dari biji Moringa oleifera memiliki $\mathrm{IC}_{50}$ $91.13 \mu \mathrm{g} / \mathrm{mL}$ lebih rendah dibandingkan fraksi ekstrak etil asetat dari daun dengan $\mathrm{IC}_{50}$ $5.72 \mu \mathrm{g} / \mathrm{mL}$. Penelitian Sudaryanto (2016) dan Unuigbe, CA., (2014) menggunakan moringa seed oil hasil ekstraksi dengan pelarut organik, tidak dalam bentuk sediaan sedangkan penelitian ini menggunakan moringa seed oil yang diperoleh secara cold proses tanpa pelarut organik dan telah melalui pengolahan sehingga menjadi sediaan lotion. Mengingat senyawa anti oksidan ini sangat mudah teroksidasi baik oleh cahaya maupun udara, proses pengolahan yang salah dapat menurunkan sifat daya antioksidannya. Sementara itu aktifitas antioksidan daun kelor yang di formulasikan dalam sediaan gel memiliki daya antioksidan sedang dengan $\mathrm{IC}_{50}$ yaitu 89,3 (Hasanah et al., 2017).

Daya antioksidan berhubungan langsung dengan kandungan metabolit sekunder yang terdapat di dalam tanaman. Jumlah kandungan metabolit sekunder yang terdapat dalam tanaman, juga dipengaruhi tanah tempat tumbuh, unsur hara, dan $\mathrm{pH}$ tanah (Solekah, 2017), sehingga sumber tanaman yang berbeda lokasi tempat tumbuh dapat menghasilkan daya antioksidan yang berbeda. Rendahnya daya antioksidan dari magnesium moringa lotion dapat disebabkan sumber tanaman kelor yang digunakan sebagai bahan aktif, memang memiliki daya antioksidan yang lemah, dapat juga karena pengaruh perlakuan selama produksi seperti pemanasan, cahaya, penyimpanan dapat mempengaruhi stabilitas daya antioksidan sediaan. Saat ini masih sangat sedikit literatur yang meneliti daya antioksidan moringa seed oil yang diproses secara cold proses yang berasal dari sentra perkebunan kelor di Indonesia.

Menurut Popovic, NG., \& Ansel, (2013) 
obat dapat mempenetrasi kulit yang utuh setelah pemakaian topikal melalui dinding folikel rambut, kelenjar keringat atau kelenjar lemak atau antara sel-sel dari selaput tanduk. Apabila kulit utuh, maka cara utama untuk penetrasi obat umumnya melalui lapisan epidermis, lebih baik daripada melalui folikel rambut atau kelenjar keringat. Penyampaian obat transdermal melalui kulit ke sirkulasi sistemik menyediakan rute yang nyaman dan menawarkan banyak manfaat, seperti penghilangan first pass metabolism, peningkatan efisiensi terapi dan memelihara kestabilan obat dalam plasma, mengurangi frekuensi penggunaan obat, mengurangi efek samping dan meningkatkan kepatuhan pasien.

Terapi magnesium topikal merupakan salah satu terapi yang cukup tua, misalnya terapi berendam dengan dengan air garam dari laut mati yang dipercaya mampu menghilangkan pegalpegal dan relaksasi, yang sampai saat ini masih banyak dilakukan di masyarakat. Setelah aplikasi topikal magnesium, diperoleh data bahwa magnesium menembus stratum korneum manusia tergantung kepada jumlah konsentrasi dan lamanya waktu paparan dan folikel rambut memberikan kontribusi yang signifikan terhadap penetrasi magnesium (Chandrasekaran, NC., Washington YS., Yousuf H Mohammed., Jeffrey

\section{DAFTAR PUSTAKA}

Agoes, G. (2015). Sediaan Kosmetika (SFI-9) (Cetakan 1). Penerbit ITB.

Badan Standardisasi Nasional. (1996). Sediaan Tabir Surya. Dewan Standardisasi Nasional, 16(4399), 1-3.

Chandrasekaran, NC., Washington YS., Yousuf H Mohammed., Jeffrey EG., Michael SR, B. R. (2016). Permiation of topically aplied Magnesium ions through human skin is facilitated by hair follicles. Magnesium Research, 29(2), 35-42. https://doi.org/10.1684/mrh.2016.0402

DiNicolantonio, J. J., O’Keefe, J. H., \& Wilson, W. (2018). Subclinical magnesium deficiency: A principal driver of cardiovascular disease and a public health crisis. Open Heart, 5(1). https://doi.org/10.1136/openhrt-2017000668

Hasanah, U., Yusriadi, Y., \& Khumaidi, A. (2017). Formulasi Gel Ekstrak Etanol Daun Kelor (Moringa oleifera Lam) Sebagai Antioksidan. Natural Science: Journal of Science and Technology, 6(1), 46-57.
EG., Michael SR, 2016),

Pemberian lotion kombinasi magnesium dan moringa seed oil ini sebagai massage lotion diharapkan dapat meningkatkan nilai kemanfaatan sediaan sebagai cosmeceutical, memberikan intake magnesium secara transdermal, sekaligus memberikan perawatan kulit dengan kandungan moringa seed oil yang kaya dengan vitamin dan mineral, collagen, dan omega 3 , omega 6 , asam oleat, serta senyawa metabolit sekunder lainnya (Krisnadi, 2015).

\section{SIMPULAN}

Berdasarkan hasil penelitian dan pembahasan dapat disimpulkan bahwa seluruh formula memenuhi persyaratan $\mathrm{pH}(5,0-5,5)$. Beberapa formula tidak memenuhi persyaratan viskositas, daya sebar dan bobot jenis. Hanya formula 4 yang memenuhi persyaratan sediaan lotion. Keseluruhan formula memiliki daya antioksidan sangat lemah. Untuk pengembangan penelitian selanjutnya dapat dilakukan pemilihan sumber moringa seed oil yang memiliki daya antioksidan paling baik dari berbagai sentra perkebunan kelor sebelum diformulasikan dalam berbagai bentuk sediaan farmasi. https://doi.org/10.22487/25411969.2017.v 6.i1.8079

Karim, K., Jura, M. R., \& Sabang, S. M. (2015). Uji aktivitas antioksidan ekstrak daun patikan kebo (euphorbia hirta 1.). Jurnal Akademika Kimia, 4(2), 56-63.

Kass, L., Rosanoff, A., Tanner, A., Sullivan, K., McAuley, W., \& Plesset, M. (2017). Effect of transdermal magnesium cream on serum and urinary magnesium levels in humans: A pilot study. PLoS ONE, 12(4), 1-11. https://doi.org/10.1371/journal.pone.0174817

Krisnadi, AD. (2015). Kelorina. In Kelor Super Nutrisi (2015th ed.).

Lachman, L; H, Lieberman; Joseph, L. . (2008). Teori dan Praktek Farmasi Industri II (Ed.3). UI-Press.

Molyneux, P. (2004). The use of the stable free radical diphenylpicrylhydrazyl (DPPH) for estimating activity. Songklanakarin antioxidant technol, 26(2), 211-219.

National Institutes of Health NIH. (2018). Magnesium-Health Professional Fact Sheet. Fact Sheet for Health Professionals (pp.1-9). 
Popovic, Nicholas G., Ansel, H. C. (2013). First Pass Metabolism Intro.pdf. 6-21.

Solekah, F. (2017). Perbedaan Ketinggian Tempat Tumbuh Terhadap Kandungan Flavonoid dan Beta Karoten Buah Karika (Carica pubescens) Daerah Dieng Wonosobo. Prosiding Seminar Nasional Pendidikan Biologi Dan Biologi, B75-81.

Sudaryanto. (2016). aktivitas antioksidan minyak biji kelor yang diekstraksi dengan $\mathrm{N}$ Hexana, Metanol dan Etanol. Journal Teknotan, 10, 16-21.

Sugihartini, N., Fajri, M. A., \& Rahmawati, D. R. (2019). Formulation of Moringa oleifera Leaf Extract in Lotion and Gel as Sunscreen. Proceedings of the 1 st Muhammadiyah International Conference on Health and Pharmaceutical Development, 154-158. https://doi.org/10.5220/0008241001540158

Suphachai, C. (2014). Antioxidant and anticancer activities of Moringa oleifera leaves. Journal of Medicinal Plants Research, $8(7)$, 318-325. https://doi.org/10.5897/jmpr2013.5353.

Suryadevara V, Doppalapudi S, S. R. L., \& Anne R, M. M. (2018). Formulation and
Evaluation of Anti-Inflammatory Cream by Using Moringa oleifera Seed Oil. Pharmacognosy Research, 10(2), 95-204.

Tranggono, R. dan L. F. (2007). Buku Pegangan Ilmu Pengetahuan Kosmetika (J. Djajadisastra (ed.)). Gramedia Pustaka Utama.

Unuigbe, Charles A., et all. (2014). Phytochemical and antioxidant evaluation of Moringa oleifera (Moringaceae) leaf and seed. Pharmacy and Bioresources, 11, 51-57.

https://www.researchgate.net/publication/2 77939976_Phytochemical_and_antioxidan t_evaluation_of_Moringa_oleifera_Moring aceae_leaf_and_seed

Warra, A. (2014). Research and Reviews: Journal of Pharmaceutics And Nanotechnology A Review of Moringa Oleofera Lam Seed Oil Prospects in Personal Care. RRJPNT, 2(3), 31-34.

Werdhasari, A. (2014). Peran Antioksidan Bagi Kesehatan. Indonesian Journal of Biotechnology Medicine, 3(2), 59-68. https://doi.org/10.22435/jbmi.v3i2.4203.5968. 